\title{
The determinants and impact of access to agricultural credit on productivity by farmers in Nigeria; Evidence from Oyo State, Nigeria.
}

\author{
Ajayi Samson \\ Department of Finance, University of Lagos, Nigeria. \\ Olalekan Obademi \\ Department of Finance, University of Lagos, Nigeria.
}

\begin{abstract}
The focus of this study is to examine the determinants as well as impact of agricultural credit accessed by farmers in Oyo State on productivity, using Ibarapa region as a case study. Descriptive statistics, Probit model and Regression analysis as estimation techniques were used and data were sourced through structured questionnaire. The results obtained from the probit model shows that the model is well fitted for the analysis by revealing the factors that influence farmers' access to Microfinance bank loan while the results obtained from the regression model revealed that the independent variables engaged in the equation for crop enterprise namely, farm size, labor cost, cost of seeds and amount of credit obtained have positive impact on productivity. Also, Chow-test result shows that the output of Microfinance bank credit beneficiaries is significantly different from that of non-beneficiaries of Microfinance bank credit. Based on the findings, it is recommended that savings mobilization by the Microfinance banks should be encouraged, and long loan repayment period of about two years coupled with low interest rate of at most $5 \%$ should be pursued. In addition, farmers should be insured against losses and microfinance bank credit programme should be gender sensitive as women have been reported to be equally efficient in farming activities like their men counterparts. Finally, Microfinance bank should inculcate into their credit programme, input availability (fertilizer, seed, medication etc) which will to a great extent increase agricultural productivity.
\end{abstract}

\section{INTRODUCTION}

The importance of the agricultural sector to the Nigerian economy cannot be overemphasized against the backdrop of the economic diversification drive being pursued by the government. Agricultural sector being one of the vital sectors in Nigerian economy accounts for almost one third of the Gross Domestic Product (GDP) and employs about two third of the labour force directly and indirectly. Prior to the era of oil boom, agriculture was the mainstay of the economy and was the highest source of revenue of government. Agriculture makes its contribution to economic development by providing food for the populace, raw materials for industrial use, serves as a source of employment generation, and also as a source of revenue generation for the government. The inadequate funding of the sector, lack of adequate infrastructural facilities and the neglect of the rural sector where small scale farmers live in large numbers has caused tremendous decline in the agricultural productivity in Nigeria.

There is a general consensus that agricultural credit is germane in ensuring agricultural sector development but the fact that most farmers are resource-poor due to a cycle of low level of income, low level of savings, lack of adequate infrastructural facilities, inadequate collateral security and inability to access adequate credit in terms of volume of credit and timeliness has hindered productivity despite the huge potential of farmers especially in Oyo State and in particular the study area which has vast arable land and predictable rainfall pattern. 
Several studies have highlighted the negative impacts of inadequate credit to farmers, for example Bolarinwa and Oyeyinka (2009) in their study opined that inadequate credit provision and poor marketing systems have reduced agriculture productivity drastically to the extent that food importation has been on the increase in recent years. The study further pointed out that agricultural activities in Nigeria and other developing countries were predominantly dominated by small scale farmers, which are faced with several constraints and barriers limiting their overall farming activity and output thus ultimately affecting agricultural output negatively. Olagunju and Adeyemo (2008) also reported that the lack of a formal national credit policy and paucity of credit institutions that should assist small scale farmers hinders the contribution of the agricultural sector to the economy

Although governments have come up with some policies and special Presidential Initiatives aimed at addressing the inability of agricultural output to meet up with the country's demand for agricultural products, however credit institutions have over the years drifted away from lending tosmall-scale farmers who form the larger part of the farming population, citing reasons such as high default rates, difficulty in monitoring numerous individuals whose loans do not provide much return on investment, as well as not being cost effective (Jumare, 2006).

Generally, farmers often have limited access to credit due to their inability to offer acceptable marketable security or collateral. Consequently, small scale farmers are caught in the vicious cycle of poverty, where low level of income leads to a low level of capital investment and low level of agricultural productivity. Many studies have shown that credit institutions give loans to farmers, but the impact is not significant and this has been a major concern to policy makers and also the government. However, only few empirical studies have been carried out to identify the determinants and impacts of access to agricultural credit (among farmers) in Nigeria, and the attention being paid in this study to Oyo State and the study area of Ibarapa being a region with great agricultural potentials is instructive.

According to Okojie et al., (2010), from the gender perspective, lack of bank accounts, lack of collateral, and lack of information regarding the procedure for accessing credits from banks limit rural women's access to credit from formal institutions. Adejobi and Atobatele (2008) suggested that loan default could limit access to credit, while Agnet (2004) opined that the complex mechanism of commercial banking is least understood by the small-scale farmers, and thus, limits their access.

Rahji and Fakayode (2009) blamed the limitation on imperfect and costly information problems encountered in the financial markets; credit rationing policy; and banks' perception of agricultural credit as a highly risky venture; while Philip et al., (2009) stated that high interest rate and the short-term nature of loans with fixed repayment periods do not suit annual cropping, and thus constitute a hindrance to credit access.

In the light of the above challenges, the questions that would readily come to mind are: what are the socio-economic characteristics of the farmers in the study area, what is the volume of loan/credit obtained by the beneficiaries from banks, what are the determinants of access to the bank credit, what is the influence cum impact of credit access on agricultural productivity and what are the determinants of farmers' access and use of credit? Also it will be of interest to ask if there are gender-related factors that determine access to credit which are questions that related empirical work failed to address. 


\section{LITERATURE REVIEW}

In finance, the word credit and loan are often used interchangeably. Credit is obtaining control over the use of money at the present time in exchange for a promise to pay back at some future time (Miller 1997). According to Feder et al., (1990) credit is an important catalyst to agricultural production activities because it allows the users to satisfy the cash needs required in the production cycle which characterizes agricultural activities like pre-planting, planting and post-planting operations that are typically carried out over a long period. Thus, credit involves a temporary transfer of wealth. Hossain (1998) also noted that loan offered to smallscale entrepreneurs could increase their capital base as well as their investment, thus helping them to accumulate wealth, which can generate further employment activities. It is instructive from the study of Lekan (2009) that reported that agricultural sector's contribution to export earnings does not correlate with the increased productivity in Nigeria due to high post-harvest losses hence if farmers have better access to credit, they can do better preservation of their farm produce and also engage in some level of food processing.

Ololade and Olagunju (2013) examined the determinants of credit accessed by rural farmers in Nigeria and data collected with the aid of structured questionnaires administered on 210 respondents using multistage sampling procedure were analysed. The binomial logit model revealed that significant relationships exists between sex, marital status, lack of guarantor, high interest rate and access to credit. The variables were significant at $10 \%$.

Ijioma and Osondu (2015) focused on agricultural credit sources and determinants of credit acquisition by farmers in Idemili local government area of Anambra State, Nigeria with the result revealing that age, household size, membership of cooperative societies, marital status, education level, farm size and amount of loan, as significant predictors of amount of agricultural credit acquired by farmers.

Adekoya (2014) examined the patterns and determinants of agricultural credit use among farming households in some other parts of Oyo State, Nigeria. Descriptive statistics and multiple regressions were used to analyze the data obtained from a cross sectional survey of 114 farm households drawn by multi-stage random sampling technique. The study revealed that the major constraints faced by the rural farm households in accessing loans include high interest rate and lack of collateral while farm size, membership of a social organization, number of adult males in households and off farm income had positive significant influence on the amount of credit the household can secure.

Etonihu, Rahman and Usman (2013) identified the determinants of access to agricultural credit among smallholder farmers in Doma Local Government Area (LGA) of Nasarawa State, Nigeria and data were obtained from 125 farmers by administered structured questionnaire through a two stage random sampling technique. Descriptive statistics and stepwise linear regression model were used to analyze the data and it was observed that education, distance to source of credit and types of credit source were significant factors affecting farmers' accessibility to agricultural credit in the study area.

This study is thus geared towards investigating the determinants and impact of agricultural credit on productivity by farmers in the study area aforementioned.

The hypothesis underpinning this study is thus stated:

Ho: The socio-economic status of farmers impacts significantly on access to credit

Ha: The socio-economic status of farmers does not impact significantly on access to credit. 
Ho: Access to credit impacts positively and significantly on agricultural productivity in the study area.

Ha: Access to credit does not impact positively and significantly on agricultural productivity in the study area.

\section{METHODOLOGY}

For this study the linear regression model of the ordinary least square (OLS) approach was used to test hypothesis with a view to ascertaining if the considered explanatory variables have significant effects on the level of access to credit facility received and used by farmers.

The use of (OLS) was informed by the theoretical fact that under normality assumption i.e. the OLS estimator is normally distributed and is said to be a best and unbiased linear estimator (Gujarati, 1995). Similarly, Olayemi (1998) established that agricultural production data usually fit better in a Cobb-Douglas function, as a result the OLS function would be presented in equation form.

The objective to identify determinants of access to formal credit from community Banks was analyzed through probit model and it is implicitly specified as follows;

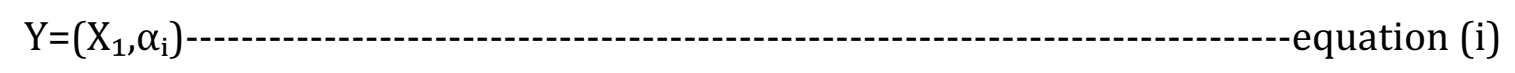

The Probit equation is expressed as:

$$
Y=a_{0}+a_{1} X_{1}+a_{2} X_{2}+a_{3} X_{3}+a_{4} X_{4}+a_{5} X_{5}+a_{6} X_{6}+a_{7} X_{7}+a_{8} X_{8}--- \text { equation (ii) }
$$

Where $Y=$ depicts level of access such that 1 , Access to community Bank credit 0 , no access to microfinance bank credit $\alpha_{i}=$ are parameters to be estimated $X_{1}=$ Membership of organization (ME0) Belonging $=1$, Not Belonging $=0, X_{2}=$ Loan size (LOSZ) in naira, $X_{3}=$ Possession of collateral security (COLL); Yes $=1$, No $=0, X_{4}=$ Type of enterprises (TEP) $\mathrm{crop}=1$, livestock $=$ $0, X_{5}=$ Amount of savings with microfinance banks (SAV) in naira, $X_{6}=$ Guarantee market for enterprise produce $(\mathrm{GM})$ yes $=1$, No $=0, \mathrm{X}_{7}=$ Educational level (EDUL) in years and $\mathrm{X}_{8}=$ Farming experience (FAEXP) in years.

The objective related to determining and comparing the impact of agricultural productivity of loan beneficiaries and non- beneficiaries was analyzed through Ordinary Least Square Regression Model (OLS).

$$
\mathrm{Y}=\mathrm{f}\left(\mathrm{X}_{1}\right)
$$

Since agricultural production data usually fit better in a Cobb-Douglas function, then the OLS function would be presented in equation form as:

$$
\log Y=a_{0}+a_{1} \log X_{1}+a_{2} \log X_{2}+a_{3} \log X_{3}+a_{4} \log X_{4}+a_{5} \log X_{5}+\log m-------(i v)
$$

Where $Y=$ Value of crop produced in naira, $\mathrm{a}_{0}$ to $\mathrm{a}_{5}=$ coefficients to be estimated, $\mathrm{X}_{1}=$ farm size cultivated (PLOT SZ), $\mathrm{X}_{2}=$ Labour (LAB) in manday, $\mathrm{X}_{3}=$ Planting Material (PLTM) in $\mathrm{kg}, \mathrm{X}_{4}=$ Fertilizer (FERT) in kg, $X_{5}=$ Amount of credit from microfinance bnk (CRDM) in naira, $M=$ Error-term

$$
\begin{aligned}
& Y=\log \left(X_{1} b\right)-(v) \\
& L \log Y=f\left(\log a_{0}+a_{1} \log X_{1}+a_{2} \log X_{2}+a_{3}+\log X_{3}+a_{4} \log X_{4}+a_{5} \log X_{5}+\log m\right)-(v i)
\end{aligned}
$$


Where $\mathrm{Y}=$ Value of crop produced in naira, $\mathrm{a}_{0}$ to $\mathrm{a}_{5}=$ coefficient to be estimated, $\mathrm{X}_{1}=$ Farms size cultivated (PLOTSZ), $X_{2}=$ Labour (LAB) in manday, $X_{3}=$ Planting material (PLTM) in kg, $X_{4}$ $=$ Fertilizer (FERT) in $\mathrm{kg}, \mathrm{X}_{5}=$ Amount of credit from source other than microfinance bank $(\mathrm{CRDM})$ in naira and $\mathrm{m}=$ Error- term

Chow test was used to examine significant difference in the productivity of microfinance bank credits beneficiaries and non- beneficiaries.

Chow- test formula is given as:

$$
\begin{aligned}
& \quad \mathrm{FK}_{1}, \mathrm{~N}_{1}+\mathrm{N}_{2}-2 \mathrm{~K}=\mathrm{Sc}-\left[\mathrm{S}_{1}+\mathrm{S}_{2} \zeta \mathrm{K}\right. \\
& \mathrm{S}_{1}+\mathrm{S}_{2} /\left(\mathrm{N}_{1}+\mathrm{N}_{2}=2 \mathrm{~K}\right)
\end{aligned}
$$

Where; Sc $=$ sum of squares residual from pooled data, $S_{1}=$ sum of squares from the community bank credit beneficiaries, $S_{2}=$ sum of squares from the non-community bank credit beneficiaries $\mathrm{N}_{1}$ and $\mathrm{N}_{2}$ are observations in each group and $\mathrm{K}=$ degree of freedom.

The a-priori specification of coefficients is expected to be of the form; $a_{1-a_{8}}>0$ (i.e. expected signs and size of the coefficients of the explanatory variables). The reason for this is that all the incorporated explanatory variables are expected to propel farm output. Descriptive analytical tools such as frequency tables, charts, counts, means and percentages were used in presenting the socio-economic characteristics and also to categorize farmers into small, medium and large scale.

Probit regression model of the ordinary least square (OLS) approach was used to test hypothesis one with a view to ascertaining if the Age, Education, Family size, Farming experience, and Farm size variants of the small scale farmers have significant effect on the level of credit access among farmers. The regression analysis was done using E-views and significance was based on an alpha of 0.05 , as this will determine the order of importance of the explanatory variables in explaining the variation observed in the dependent variables.

Primary data sourced through the use of questionnaire was used. The target population for the study were farmers in Ibarapa region, Oyo State. For convenience, the entire population of the study area was stratified into three zones in accordance with the three Local Governments in the study area as follows; Ibarapa East Local Government Area, Ibarapa Central Local Government Area and Ibarapa North Local Government Area.

Three different samples were independently drawn one from each zone. The sample size collected from each zone was based on the proportion of the farming families it contained from the total. Two sets of questionnaires were prepared and administered to farmers. Two stage stratified random sampling was used in selecting respondents. The first stage was the stratification of the respondents into beneficiaries and non-beneficiaries of microfinance bank credit. This was followed by (the second stage) the stratification of beneficiaries into crop and livestock producers. Based on the population list of the farmers (beneficiaries and nonbeneficiaries which consists of crops and livestock farmers) a total of one hundred and eighty (180) questionnaires were administered. 


\section{RESULT AND DISCUSSION OF FINDINGS}

Table 1: Respondents' Educational Level

\begin{tabular}{|l|l|l|l|l|}
\hline \multirow{2}{*}{\begin{tabular}{l} 
Level of Education \\
\cline { 2 - 5 }
\end{tabular}} & $\begin{array}{l}\text { Microfinance Bank Credit } \\
\text { Beneficiaries }\end{array}$ & \multicolumn{2}{l|}{$\begin{array}{l}\text { Microfinance Bank Credit } \\
\text { Non- Beneficiaries }\end{array}$} \\
\cline { 2 - 5 } & $\begin{array}{l}\text { Absolute } \\
\text { Frequency }\end{array}$ & Percentage & $\begin{array}{l}\text { Absolute } \\
\text { Frequency }\end{array}$ & Percentage \\
\hline No Education & 5 & 7.69 & 18 & 32.73 \\
\hline Primary & 15 & 23.08 & 6 & 10.91 \\
\hline Secondary & 19 & 29.33 & 13 & 23.64 \\
\hline Tertiary & 24 & 36.92 & 18 & 32.72 \\
\hline Others & 2 & 3.08 & - & - \\
\hline Total & 65 & 100 & 55 & 100 \\
\hline
\end{tabular}

Source Field Survey, 2014

Table 1 above shows the level of education attained by respondents. It reveals that $7.69 \%$ of beneficiaries were not educated at all, followed by those with only primary education representing 23.08\%. Among the non-beneficiaries, $10.91 \%$ attained primary education followed by those that attained secondary education representing 23.65. Further analysis reveals that $36.92 \%$ and $32.72 \%$ attained tertiary education for both beneficiaries and nonbeneficiaries respectively. The distribution of the educational levels in favour of the beneficiaries goes to support the assertion that some form of formal education is usually necessary for farmers to be able to communicate effectively with the bank officers and pus through the cumbersome procedure in the procurement of loans from most of the financial institutions.

Table 2: Farmers Responses to Major Occupation

\begin{tabular}{|l|l|l|l|l|}
\hline Major Occupation & \multicolumn{2}{|l|}{$\begin{array}{l}\text { Microfinance Bank Credit } \\
\text { Beneficiaries }\end{array}$} & \multicolumn{2}{l|}{$\begin{array}{l}\text { Microfinance Bank Credit } \\
\text { Non- Beneficiaries }\end{array}$} \\
\cline { 2 - 5 } & $\begin{array}{l}\text { Absolute } \\
\text { Frequency }\end{array}$ & Percentage & $\begin{array}{l}\text { Absolute } \\
\text { Frequency }\end{array}$ & Percentage \\
\hline Farming & 33 & 50.77 & 24 & 43.64 \\
\hline Civil Service & 29 & 44.62 & 2 & 3.63 \\
\hline Trading & 2 & 3.08 & 13 & 23.64 \\
\hline Hunting & 1 & 1.5 & 1 & 1.82 \\
\hline Others & - & - & 15 & 27.27 \\
\hline Total & 65 & 100 & 55 & 100 \\
\hline
\end{tabular}

Source Field Survey, 2014

Table 2 above shows farmers' responses to major occupation in Ibarapa Area. In ranking the occupations, both the beneficiaries and non-beneficiaries identified farming as the most important occupation represented by $50.55 \%$ and $43.64 \%$ respectively. The beneficiaries indicated civil service as an important occupation and trading as less important. Both represented $44.62 \%$ and $3.08 \%$ respectively while the non-beneficiaries regarded trading as 
an important occupation and civil service as less important, representing $23.64 \%$ and $3.63 \%$ respectively.

Table 3: Method of Land Acquisition

\begin{tabular}{|l|l|l|l|l|}
\hline \multirow{2}{*}{ Method of Acquisition } & \multicolumn{3}{|l|}{$\begin{array}{l}\text { Microfinance Bank Credit } \\
\text { Beneficiaries }\end{array}$} & \multicolumn{2}{l|}{$\begin{array}{l}\text { Microfinance Bank Credit } \\
\text { Non- Beneficiaries }\end{array}$} \\
\cline { 2 - 5 } & $\begin{array}{l}\text { Absolute } \\
\text { Frequency }\end{array}$ & Percentage & $\begin{array}{l}\text { Absolute } \\
\text { Frequency }\end{array}$ & Percentage \\
\hline I Purchase & 10 & 15.38 & 5 & 9.09 \\
\hline II Inheritance & 20 & 30.77 & 25 & 45.45 \\
\hline III Gift & 6 & 9.23 & 12 & 21.82 \\
\hline IV Rent/Lease & 8 & 12.31 & 5 & 9.08 \\
\hline V Family/Comm & 20 & 30.77 & 7 & 12.73 \\
\hline I \& II & 1 & 1.54 & 1 & 1.82 \\
\hline Total & 65 & 100 & 55 & 100 \\
\hline
\end{tabular}

Source Field Survey, 2014

Table 3 above shows the various methods of land acquisition among the farmers. The table reveals that equal percentages (i.e. 30.77\%) of the beneficiaries inherited their farm lands from parents and family/ community. However, $15.38 \%$ obtained their farmland through purchase and $1.54 \%$ through purchase and inheritance. On the other hand, $9.09 \%$ of the nonbeneficiaries purchased the land on which they farm followed by those that acquired theirs through inheritance representing $45.45 \%$ and another $21.82 \%$ through gift, while $12.73 \%$ and $1.82 \%$ obtained their farmlands from family and both and inheritance respectively. This result indicates while majority of the non-beneficiaries famers do not pay for the land on which they farm and some of the loan beneficiaries do. One would then expect the beneficiaries to be more efficient in their land utilization because of the money they are paying in return for the land use. 
Table 4: Loan Size, Average Repayment Time and Level of Satisfaction of Request for Loan

\begin{tabular}{|c|c|c|c|c|c|c|c|}
\hline \multirow[t]{2}{*}{$\begin{array}{l}\text { Name } \\
\text { of } \\
\text { Bank }\end{array}$} & \multirow[t]{2}{*}{$\begin{array}{l}\text { Year of } \\
\text { Operation }\end{array}$} & \multicolumn{2}{|c|}{$\begin{array}{l}\text { Average Loan Size } \\
\text { (N) }\end{array}$} & \multicolumn{2}{|c|}{$\begin{array}{l}\text { Average } \\
\text { Repayment } \\
\text { Time (Years) }\end{array}$} & \multirow{2}{*}{$\begin{array}{l}\text { Level of } \\
\text { Satisfaction } \\
\text { for } \\
\text { Farmers } \\
\text { Request for } \\
\text { Loan }\end{array}$} & \multirow[t]{2}{*}{$\begin{array}{l}\text { Reasons for Level } \\
\text { of Satisfaction }\end{array}$} \\
\hline & & Crop & Livestock & Crop & Livestock & & \\
\hline L.C.B & 13 & 30,000 & 50,000 & 1 & $11 / 2$ & Satisfied & $\begin{array}{l}\text { Farmers come and } \\
\text { collect loan through } \\
\text { local cooperative } \\
\text { repayment. }\end{array}$ \\
\hline E.C.B & 14 & 20,000 & 50,000 & 1 & 1 & Satisfied & $\begin{array}{l}\text { Many farmers come } \\
\text { for credit every year. }\end{array}$ \\
\hline I.C.B & 12 & 30,000 & 40,000 & 1 & 1 & $\begin{array}{l}\text { Less } \\
\text { Satisfied }\end{array}$ & $\begin{array}{l}\text { Improper utilization } \\
\text { of loan and high rate } \\
\text { of default. }\end{array}$ \\
\hline A.C.B & 13 & 20,000 & 50,000 & $11 / 2$ & 2 & Satisfied & $\begin{array}{l}\text { People are } \\
\text { committed to } \\
\text { farming. }\end{array}$ \\
\hline T.C.B & 11 & 50,000 & - & 1 & - & Satisfied & $\begin{array}{l}\text { The land is fertile for } \\
\text { farming. }\end{array}$ \\
\hline I.C.B* & 11 & 30,000 & 50,000 & 1 & 1 & Satisfied & $\begin{array}{l}\text { Farmers wish for } \\
\text { loans and low rate of } \\
\text { default. }\end{array}$ \\
\hline
\end{tabular}

Source: L.C.B, E.C.B, I.C.B, A.C.B, T.C.B, I.C.B*, Data, 2014

Note: L.C.B = Lanlate Microfinance Bank, E.C.B = Eruwa Microfinance Bank. I.C.B = Igboora Microfinance Bank, A.C.B = Ayete Microfinance Bank, T.C.B = Tapa Microfinance Bank, I.C.B = Igangan Microfinance Bank

Table 4 above summarizes the credit institutions, years of operation, average loan, size for farming, average loan repayment time, level of satisfaction of the credit institutions on farmers request for loans and reasons given for the level satisfaction indicated. The table reveals that there are six Microfinance banks in the study area namely: Lanlate Microfinance Bank, Eruwa Microfinance Bank, Igboora Microfinance Bank, Ayete Microfinance Bank, Tapa Microfinance Bank and Igangan Microfinance Bank. L.C.B gives an average loan per farmer for both crops and livestock at N30,000 and N50,000 respectively, likewise I.C.B* gives the same as L.C.B. E.C.B and A.C.B gives loan per farmer for crops at 20,000 and livestock at 50,000. But I.C.B gives average loan of 30,000 for crop farmers and 40,000 for livestock farmers.

However, only A.C.B gives loan for an average repayment time up to two years but all other banks gives for an average of one to one and half year. I.C.B indicated less satisfaction with the farmers' request for loan and the reason given by the bank was improper utilization of loan granted and high rate of defaults. 
Table 5: Result of the Probit Model for the Determinants of Farmers' Access to Microfinance bank Loan

\begin{tabular}{|l|l|l|l|}
\hline Variables & Coefficient & Standard Error & Z-ratio \\
\hline Constant & 0.333069521 & 0.79850 & 0.6766 \\
MEO & -0.87627259 & 0.26938 & -0.325 \\
LOSZ & 0.92842111 & 1.04255 & 1.243 \\
COLL & 0.60144931 & 0.27032 & $2.225^{* *}$ \\
TEP & -0.17225272 & 0.10911 & -1.579 \\
SAV & 0.85322467 & 0.30129 & $2.832^{* * *}$ \\
GM & 0.73475599 & 0.30763 & $2.388^{* *}$ \\
EDUL & 0.59572249 & 0.34511 & $1.726^{*}$ \\
FAEXP & -0.97974294 & 0.15564 & -0.629 \\
\hline
\end{tabular}

Source: Computer Printout, 2014

$* * *, * *, *$ signifies level of significant at $1 \%, 5 \%$ and $10 \%$ respectively Chi square $=26.16506$ Log-likelihood $=-69.67798$

Farmers' access to Microfinance bank credit was analysed using probit model and factors that influence farmers' access to Microfinance bank credit were determined. The result of the probit model in table 5 above shows that guarantee market for farmers' product, amount of savings with Microfinance bank, possession of collateral by farmers and year of education of farmers access to credit. It therefore implies that, guarantee market for product produced as a result of credit increases the probability of farmers' access to credit. Similarly, increase in the level of farmers' saving with Microfinance banks increases the probability of farmers' access to Microfinance bank credit. Also, farmers that possess collateral are able to access credit relative to those that do not. Finally, farmers with considerable years of education have high probability to credit access. Loan size is not significant because most of the beneficiaries were given small loans based on collateral presented. The significant of chi-square shows that Probit model is best fitted for the analysis.

Table 6: Results of Ordinary Least Square Regression Analysis

\begin{tabular}{|l|l|l|l|}
\hline Variables & Coefficient & Standard Error & t-ratio \\
\hline Constant & 9.97734807 & 1.1180164 & 8.924 \\
PLOTSZ & 0.22276653 & 0.0328819 & $6.770^{* * *}$ \\
LAB & 0.17382996 & 0.0355662. & $4.890^{* * *}$ \\
PLTM & 0.51690571 & 0.1429976 & $3.615^{* * *}$ \\
FERT & 0.53515134 & 0.1120691 & 0.478 \\
CRDM & 0.18217581 & 0.0483349 & $3.772^{* * *}$ \\
\hline
\end{tabular}

Source: Computer Printout, 2014

$* * *, * *, *$ signifies level of significant at $1 \%, 5 \%$ and $10 \%$ respectively Durbin-Watson Statistic $=1.23380$ Log-likelihood $=73.0068 \quad \mathrm{~N}=40$

The result in table 6 above shows that farm size, labour and planting materials used by the arable crop farmers as well as amount of credit obtained are significant factors that influence output of arable crop farmers. Fertilizer input is not significant because of non-availability, which makes farmers to either use small quantity or not use at all. Therefore, a $1 \%$ increase in farm size, labour used, planting material and amount of credit obtained by farmers from 
Microfinance bank will increase the output of arable crop farmers by $0.22 \%, 0.17 \%, 0.52 \%$ and $0.18 \%$ respectively.

Table 7: Result of Ordinary Least Square Regression Analysis

\begin{tabular}{|l|l|l|l|}
\hline Variables & Coefficient & Standard Error & t-ratio \\
\hline Constant & 13.03198356 & 1.1870087 & 10.979 \\
PLOTSZ & 0.69569120 & 0.0483062 & $14.401^{* * *}$ \\
LAB & 0.24281334 & 0.0258879 & $9.380^{* * *}$ \\
PLTM & 0.24500296 & 0.2582242 & 0.949 \\
FERT & 0.46927948 & 0.8790864 & -0.534 \\
CRDM & 0.84575689 & 0.1578274 & 0.536 \\
\hline
\end{tabular}

Source: Computer Printout, 2014

$* * *, * *, *$ signifies level of significant at $1 \%, 5 \%$ and $10 \%$ respectively

Durbin-Watson Statistic $=1.23380$ Log-likelihood $=73.0068 \quad \mathrm{~N}=40$

The result in table 7 above shows that farm size cultivated and labour used for farming activities are the most significant factors that influence output of crop non-beneficiaries of Microfinance bank credit. Therefore, 1\% increase in land cultivated and labour used for farming activities will increase output of non-beneficiaries arable crop producers by $0.69 \%$ and $0.24 \%$ respectively. Fertilizer, quantity of planting materials as well as amount of credit obtained for farming activities from source other than Microfinance bank were not significant. The non-beneficiaries claimed that fertilizer is usually not available during production season, and if available the cost is beyond their means. Amount of credit obtained from sources other than Microfinance bank by non-beneficiaries is not significant because of small credit size.

Table 8: Result of the Chow-Test of Significant Difference

\begin{tabular}{|l|l|}
\hline F - calculated & 60.426 \\
\hline F - tabulated & 25.284 \\
\hline Decision & Reject null hypothesis \\
\hline
\end{tabular}

Mean output of beneficiaries $=\$ 2,080,560$

Mean output of non-beneficiaries $=\mathrm{N1}, 053,140$

The result in table 8 shows that output of Microfinance bank credit beneficiaries is significantly different from that of non-beneficiaries of Microfinance bank credit. 
Table 9: Result of Ordinary Square Regression Analysis

\begin{tabular}{|l|l|l|l|}
\hline Variables & Coefficient & Standard Error & t-ratio \\
\hline Constant & 249809.60 & 223182.01 & 1.119 \\
STSZ & 113582.53 & 12794.328 & $8.884^{* * *}$ \\
FDQT & 294301.84 & 25309.448 & $11.630^{* * *}$ \\
MDEXP & 665220.57 & 47726.51 & 1.394 \\
LAB & 261149.76 & 10549.74 & $2.495^{* *}$ \\
CRDM & 80631.495 & 10704.704 & $7.532^{* * *}$ \\
\hline
\end{tabular}

Source: Computer Printout, 2014

R-Square $=0.484224 \quad \mathrm{~F}=\mathbf{0 . 3 4 8 4} * *$

$* * *, * *, *$ signifies level of significant at $1 \%, 5 \%$ and $10 \%$ respectively

Durbin-Watson statistic $=1.98034 \quad$ Log-likelihood $=333.7449 \quad \mathrm{~N}=25$

The results in table 9 above shows that stock size, feed quantity and labour used by the livestock farmers as well as amount of credit obtained are the significant factors that influence output of eggs. Medication input is not significant because of high cost of medication which made farmers to resort into traditional sources. Therefore, a 1\% increase in stock size, feed size, amount of credit obtained by the farmers from Microfinance bank and labour use by the livestock producers will increase the output of egg by $0.50 \%, 0.83 \%, 0.22 \%$ and $0.65 \%$ respectively

Table 10: Result of Ordinary Least Square Regression Analysis

\begin{tabular}{|l|l|l|l|}
\hline Variables & Coefficient & Standard Error & t-ratio \\
\hline Constant & 697958.661 & 782591.63 & 0.892 \\
STSZ & 293693.94 & 30866.45 & $9.514^{* * *}$ \\
FDQT & 567004.81 & 320624.72 & $1.868^{*}$ \\
MDEXP & 489057.54 & 279464.31 & 1.750 \\
LAB & 576218.72 & 148493.44 & 0.388 \\
CRDM & 476905.37 & 549701.38 & -0.868 \\
\hline
\end{tabular}

Source: Computer Printout, 2014

R-Square $=0.429867 \quad F=0.17072 * * *$

$* * *, * *, *$ signifies level of significant at $1 \%, 5 \%$ and $10 \%$ respectively

Durbin-Watson statistic $=1.80565 \quad$ Log-likelihood $=253.005 \quad \mathrm{~N}=1.7$

The result in table 10 above shows that stock size and quantity of feed used for livestock activities are the significant factors that influence output of livestock for non-beneficiaries of Microfinance bank credit, therefore a 1\% increase in stock size and quantity of feed used for livestock activities will increase output of non-beneficiaries livestock producers by $0.18 \%$ and $0.10 \%$ respectively.

Table 11: Result of the Chow-test of Significant Difference

\begin{tabular}{|l|l|}
\hline F - calculated & 15.086 \\
\hline F - tabulated & 23.521 \\
\hline Decision & Reject null hypothesis \\
\hline
\end{tabular}

Mean output of beneficiaries $=200,570 \mathrm{~kg}$ 
Mean output of non-beneficiaries $=100,314 \mathrm{~kg}$

The result in table 11 above shows that the credit of Microfinance bank beneficiaries (i.e farmers) is significantly different from that of Microfinance bank non-beneficiaries.

In ranking the factors, high cost of transportation from the farmers' settlement to the credit source was found to have a very high effect on farmers' accessibility to credit. Similarly, other factors that are found to have high effect on their accessibility to agricultural credit are: Small size of credit usually given, the need to fill-in forms before obtaining credit, the need to produce collaterals before credit is given and the need to bribe officers before securing credit

Table 12 Impact of Access to Agricultural Credit among Farmers

\begin{tabular}{|l|l|l|}
\hline Perceptions & Absolute Frequency & Percentage \\
\hline Better-off & 60 & 92.30 \\
\hline Same as before & 3 & 4.62 \\
\hline Worse off & 1 & 1.54 \\
\hline Undecided & 1 & 1.54 \\
\hline Total & 65 & 100 \\
\hline
\end{tabular}

Source: Field Survey, 2014

Table 12 above shows the aggregate perception of the impact of access to agricultural credit among farmers in the study area. It reveals that majority of the loan beneficiaries representing $92.30 \%$ say they have been better-off than before as a results of the credit they received, while $1.54 \%$ claimed to have been worse off due to the credit they received; $4.62 \%$ declared that they were the same as before receiving credit.

\section{CONCLUSION AND RECOMMENDATIONS}

The study revealed that the principal determinant by the credit institutions in deciding whether to grant a loan to a farmer as well as major problems faced by these banks regarding the granting of agricultural loan was inadequate collateral. The major problems encountered by the banks are shortage of funds and inability to recover loans from their customers (farmers). With regards to the farmers, the major problems are inadequate collaterals and improper utilization of fund. In general however, poor engagement between banks and farmers was identified as the major problem.

Result obtained from the probit model show that the model is well fitted for the analysis by revealing the factors that influence farmers' access to Microfinance bank loan while the results obtained from the regression model revealed that the independent variables engaged in the equation for crop enterprise namely, farm size, labor cost, cost of seeds and amount of credit obtained have positive impact on the dependent variable (i.e. output). Similarly, the independent variables engaged in the equation for livestock enterprise namely: quantity of foundation stock, feed labour and amount of credit obtained have a positive impact on the dependent variable (i.e output).

The study further revealed that fertilizers, chemicals, seeds and credit received had significant effect on the output generated from crop related enterprises. Similarly, foundation stock, veterinary drugs and credit received had significant effect on output generated from livestock enterprise. The chow-test result of significant difference between crop beneficiaries and nonbeneficiaries of microfinance bank shows that output of microfinance bank credit beneficiaries 
is significantly different from that of non-beneficiaries of microfinance bank credit and for livestock beneficiaries and non-beneficiaries of microfinance bank.

Small size of loan was usually given to and credit facilities to farmers is very poor and limited because among other things, they are unable to offer acceptable security. Non-availability of inputs in the local markets especially fertilizer and high cost of input restrict farmers from effective utilization of the credit received for food production. Credit worthiness associated with enough collateral were some of the major factors considered by the credit officers.

It is thus recommended that large volume of idle funds in the rural economy should be tapped and made available to those that need them, to enhance their agricultural production. All that needs to be done to mobilize these savings is to educate the rural people. Through savings mobilization, the problem of shortage of funds by the microfinance banks would be reduced if not completely eliminated. Bureaucratic procedures such as granting loan could be minimized when traditional village leaders supervise the operations for collective. The interest rate to be charged should be 5\% and loan repayment period should be 2years for both crops and livestock farmers. Farmers should insure against loss of crops and livestock arising from drought, pest and diseases. This insurance policy would help sustain the funds mobilized through reduction of credit repayment risk.

Also gender sensitivity in microfinance bank credit programme review is important given the fact that women have been reported to be equally efficient in farming activities like their men counterparts. Gender sensitive financial inclusion in microfinance bank credit programme is important given the fact that women have been reported to be equally efficient in farming activities like their men counterparts. It may not be out of place also for microfinance banks to include input availability (fertilizer, seed, medication, etc.) in the microcredit framework to the beneficiaries which will to a great extent increase agricultural productivity.

\section{References}

Adejobi, 0. and Atobatele, J. T. (2008). An analysis of Loan Delinquency among Small-Scale Farmers in Southwestern, Nigeria: Application of Logit and Loan Performance Indices. East African Agricultural and Forestry Journal, 74(3).

Adekoya, O. A. (2014). The Patterns and Determinants of Agricultural Credit use Among Farm Households in Oyo State, Nigeria. Asian Economic and Financial Review, 4(10): 1290-1297.

Agnet, A. (2004). Making Farm Credit work for the Small-Scale Farmers. http://www.agnet.org/library/nc/145b/. Accessed on July 20, 2010.

Bolarinwa, K. K. and Oyeyinka, R. A. (2009) Using Nigeria Agricultural Cooperative and Rural Development Bank Small Holder Direct Loan Scheme to Increase Agricultural Production in Rural Oyo State, Nigeria. International Journal of Agricultural Economics and Rural Development 2(1).

Etonihu, K. I., Rahman, S. A. \& Usman, S. (2013) Determinants of Access to Agricultural Credit among Crop Farmers in a Farming Community of Nasarawa State, Nigeria. Journal of Development and Agricultural Economics, 5(5): 192-196.

Feder, G., Lan, L. J., Lin J. Y., \& Luo, X. (1990). The Relationship between Credit and Productivity in Chinese Agriculture: A Microeconomic Model of Disequilibrium. American Journal of Agricultural Economics, 72: 11511157.

Gujarati, D. (1995). Basic Econometrics. New York: McGraw Hill Printing Press.

Hossain, M. (1998). Credit for the Alleviation of Rural Poverty: The Grameen Bank in Bangladsh. IFFRI Research, No.65.

Ijioma, J. C, and Osondu, C. K. (2015). Agricultural Credit Sources and Determinants of Credit Acquisition by Farmers in Idemili Local GovernmentArea of Anambra State, Nigeria. Journal of Agricultural Science and Technology, 3(5): 34-43. 
Jumare, B. M., (2006). Financial Management in Local Government. Lagos: NOUN: BHM 641

Lekan Emmanuel Obademi (2008) "Food security and the empirical analysis of the gaps in agricultural sector's contribution to Nigeria's economic growth and development" Covenant Journal of Business and Social Sciences Vol2, No $1 \& 2$ pp163-174.

Miller, M. H. (1997). Debt and Taxes. Papers and Proceedings of the Thirty-Fifth Annual Meeting of the American Finance Association, Atlantic City, New Jersey. The Journal of Finance, 32(2).

Okojie, C., Monye-Emina, A., Eghafona, K., Osaghae, G., \& Ehiakhamen, J.O. (2010). Institutional Environment and Access to Microfinance by Self-employed women in the Rural Areas of Edo State. NSSP Brief No.14. Washington. D.C: International Food Policy Research Institute.

Olagunju, F. I. and Adeyemo, R. (2008). Evaluation of the Operational Performance of the Nigerian Agricultural Credit Cooperative and Rural Development Bank (NACRDB) in South-Western Nigeria. IJAERD Press.

Olayemi, J. K. (1998). Food Security in Nigeria. Development Policy Centre, Ibadan, Nigeria. Research Reports No.2 Ololade, R. A. and Olagunju, F. I. (2013). Determinants of Access to Credit among Rural

Farmers in Oyo State, Nigeria. Global Journal of Science Frontier Research Agricultural and Veterinary Sciences, 13(2): 17-22.

Phillip, D., Nkonya, E., Pender, J., \& Oni, O. A. (2009). Constraints to Increasing Agricultural Productivity in Nigeria: A review. Nigeria Strategy Support Program (NSSP) Background Paper No.NSSP 006.

Rahji, M.A.Y. and Fakayode, S. A. (2009). A Multinomial Logit Analysis of Agricultural Credit Rationing by Commercial Banks in Nigeria. International Research Journal of Finance and Economics, 24: 91.

http://www.eurojournals.com/finance.htm. 